\title{
Characterization and Domestication of Wild Culinary Medicinal Mushroom Pleurotus pulmonarius from Assam, India
}

\author{
Sewali Goswami*, Imtiaz Rahman and Sanjai Kumar Dwivedi \\ Defence Research Laboratory, Post Bag No-2, Tezpur, Assam, India \\ *Corresponding author
}

\section{A B S T R A C T}

\begin{tabular}{l} 
Key w or d s \\
$\begin{array}{l}\text { Pleurotuspulmonari } \\
\text { us, Spawn, Wild } \\
\text { edible, Ethnic tribe, } \\
\text { Proximate }\end{array}$ \\
\hline Article Info \\
$\begin{array}{l}\text { Accepted: } \\
\text { 26 September } 2020 \\
\text { Available Online: } \\
\text { 10 October } 2020\end{array}$ \\
\hline
\end{tabular}

Considering the increasing demand of wild edible mushrooms and to sustain regular supply throughout the year, the indigenous mushroom species consumed by the ethnic tribes of Assam was collected from their natural habitat during the month of May, 2019. Germplasm of the species, identified as Pleurotus pulmonarius was isolated and successfully domesticated using sawdust and paddy straw as substrates. Complete substrate colonization at $2 \%$ spawn rate was observed after 2-3 weeks of inoculation. Biological efficiency of $32.8 \pm 1.39$ to $69.2 \pm 0.72$ was observed in domestication trials during the period of experimentation. Proximate analysis of the cultivated fruiting bodies revealed the presence of crude protein content $9.48 \mathrm{~g}$, crude fat $0.80 \mathrm{~g}$, carbohydrate $77.02 \mathrm{~g}$ and crude fiber $34.30 \mathrm{~g} / 100 \mathrm{~g}$. No major difference in nutrient contents has been observed between cultivated and wild one. A year round cultivation trial was carried out to ensure regular source of nutrition and avenue for income generation. The successful domestication of this native species is a stepping-stone towards the cultivation of more wild edible species, consumed by the ethnic tribes of this region.

\section{Introduction}

Wild edible mushrooms have been consumed for thousands of years for its flavor, delicacy and medicinal importance (Rai et al., 2005).During recent times they are considered as functional food due its incredible impact on human health and pharmacological activity (Kumar, 2015).Over the globe, more than two thousands species of mushrooms are found in nature. However, around twenty five species are accepted as food and some of these are cultivated commercially (Hussein et al., 2015).
Oyster mushrooms are abundant in temperate and subtropical forested regions of the world. Indian Oyster, Pleurotus pulmonarius is commonly known as Indian, Phoenix, Italian or Lung Oyster. The medicinal attributes of this mushroom species has been investigated by numerous researchers throughout the world. Experiments suggest this edible mushroom species may be used as a therapeutic agent against a number of ailments (Smiderie et al., 2008; Joseet al, 2002; Ibadallah et al., 2015; Healingmushrooms.net). Several wild edible mushrooms were domesticated successfully 
over the last few years. Mushroom production technology is considered as one of the second most significant microbiological technology after the yeast (Xia et al., 2016).

Assam, is a part of Indo Burma bio-diversity hot spot, located between $24^{\circ} 44^{\prime} \mathrm{N}$ to $27^{\circ} 45^{\prime} \mathrm{N}$ Latitude and $89^{\circ} 41^{\prime} \mathrm{E}$ to $96^{\circ} 02^{\prime} \mathrm{E}$ Longitude in the North Eastern front of India. The edaphic conditions and subtropical climate with annual average rainfall $1500 \mathrm{~mm}$ and temperatures ranging from $6^{\circ}-38^{\circ} \mathrm{C}$ makes it a cradle of diverse fungal species. Wild edible mushrooms are highly coveted items of food for the ethnic tribes of this region. Rapid urbanization has resulted in the shrinkage of forest areas and erosion of forest wealth.

The rhythm of availability of wild edible mushrooms in their natural habitats depends on weather conditions. During rainy season, these edible mushroom species grows abundantly, however it is available in the natural habitat for a limited time span. None availability of these species in the dry season makes it an erratic source of nutrition. The ethnic tribes and village folk inhabiting the forest fringes have always harvested wild mushrooms from the forest for consumption and selling in local markets. Inspite of having immense potentiality, domestication is not practiced due to unawareness of cultivation technology.

In this study the authors have attempted to domesticate traditionally preferred native oyster mushroom species to make it available as a regular source of nutrition and revenue. With this objective an experiment was designed for round the year cultivation of this wild edible strain in ambient conditions using locally available material as substrates. This study includes details of the collected species, cultivation methodology and biochemical composition of the species.

\section{Materials and Methods}

\section{Collection and Isolation}

The edible mushroom was collected during the month of May, 2019 from deforested area of Biswanath district of Assam. The mushroom was found growing in clusters on wood shavings under a felled tree. The collected sample was put in a paper bag and labelled with location, date and other information for laboratory work. Near by villages were visited to collect information about the desirability among the people. The mushroom was photographed in the natural habitat during the survey and some of the collected fruiting bodies were preserved in kew cocktail solution for future reference (Courtenay, 1982).Pure culture was isolated from the collected fruiting body by tissue culture method using Streptomycin (0.01\%) amendedpotato dextrose agar (PDA) medium. Mother culture was obtained by subculturing mycelial fragments onto PDA slants and maintained at $4^{\circ} \mathrm{C}$ for further study. Various macro and micromorphological study were carried out in the laboratory. Cultural characteristics such as color, texture, growth rate, of the isolate grown on PDA were studied. The fungus was confirmed as Pleurotus pulmonarius (Kuo, 2017;Junior, 2010).

\section{Morphological Characterization}

Detailed macro morphological features such as colour, shape, size of the pileus were observed in fresh sample. A small portion of internal tissue of the fruiting body was mountedon a glass slide, in lactophenol cotton blue to observe microscopic features. Micro morphological characteristics were observed under a Zeiss AX10 microscope. All measurements (macroscopic and microscopic) were taken with the help of Image $\mathbf{J}$ software. Cultural characteristics such as colour, 
texture, density, aerial hyphae, zonation and margin of the fungal colony grown on PDA medium were observed. Growth rate of the of the isolate grown on PDA medium was calculated according to the formula $G R=\frac{r n-r 2}{t n-t 2}$

where GR is growth rate $(\mathrm{mm} /$ day), rn and $\mathrm{r} 2$ is diameter $(\mathrm{mm})$ of the colony on $7^{\text {th }}$ and $2^{\text {nd }}$ day of incubation and tn\& $\mathrm{t} 2$ represents the growth period $7^{\text {th }}$ and $2^{\text {nd }}$ days (Guadarrama-Mendoza et al, 2014).

\section{Proximate composition and Elemental analysis}

Analysis of the proximate chemical compositions (Moisture, ash, crude fiber, crude protein and crude fat) and analysis of minerals compositions, which include Magnesium (Mg), Manganese (Mn), Calcium (Ca),Nickel (Ni), Copper $(\mathrm{Cu})$, Potassium $(\mathrm{K})$, and Iron $(\mathrm{Fe})$ were conducted at NABL Laboratory, Tezpur University, Tezpur, Assam.

\section{Determination of Energy value}

Energy value was calculated using the formula: Energy value $(\mathrm{kcal} / 100 \mathrm{~g})=$ (crude protein $\mathrm{x} 4)+($ Total carbohydrate $\mathrm{x} 4)+$ (Crude fat x 9) (AOAC, 1990).

\section{Cultivation and data collection}

Cultivation was done in every month from June 2019 to May 2020 at ambient conditions.

\section{Spawn preparation}

Mushroom spawn was prepared according to Penn State Spawn Lab Procedures with slight modifications. In brief, parboiled wheat grains were mixed with $\mathrm{CaCO}_{3}(2 \%)$ and $\mathrm{CaSO}_{4}$ $(0.5 \%)$, bottled and sterilized at $121^{\circ} \mathrm{C}$ for 15 minutes. After sterilization it was inoculated aseptically with fresh culture and incubated for mycelial colonization at $28 \pm 2{ }^{\circ} \mathrm{C}$.

\section{Cultivation method}

Mixture of agricultural waste (paddy straw) and sawdust along with additives such as wheat bran $(2 \%)$ in the ratio $4: 1: 0.5, \mathrm{CaCO}_{3}$ (2\%) and $\mathrm{CaSO}_{4}(0.5 \%)$ were used as substrate. Moisture content of the substrates was adjusted to $60 \%$ approximately. One $\mathrm{kg}$ of prepared substrate was put inpolypropylene bags and autoclaved at 15lbs PSI for $1 \frac{1 / 2}{2}$ hours (Adewoyin, 2018).After cooling, the sterilized substrate bags were spawned @ 2\% and transferred to a dark room for colonization. After completion of spawn run, holes were cut at the sides of the bags and transferred to a well ventilated cropping room.

\section{Data collection}

Total yield, days taken for completion of spawn run, appearance of pinheads, date of harvest were recorded. The maximum and minimum temperature and humidity of the incubation and cropping room was recorded daily with the help of Alliance Digital Thermo Hygrometer. Light intensity in cropping room during pinhead formation and maturation phase was measured with lux meter LX-101A. Biological Efficiency (BE) was calculated according to the Chang et al., 2004 by the formula:

$$
\mathrm{BE}=\frac{\text { Weight of fresh mushroom (g) }}{\text { Weight of dry substrate (E) }} \times 100
$$

\section{Statistical analysis}

Standard Deviation of cultivation data and preparation of vertical column bar graph was done with GraphPad Prism5 software.

\section{Results and Discussion}

The species $P$. pulmonarius is a summer variety, found growing during the month of 
May. Pileus measured 4-15 cm wide, fleshy, lung shaped (Fig 1), white with yellowish brown center, surface is smooth, convex and moist when young, on maturity pileus flattened, upward curved, became rugged and dry. Margin of the pileus was smooth in the young stage, latter becoming wavy and lobate. Flesh was white and colour did not change when cut. Gills off white, crowded, decurrent, with smooth edge becoming yellowish when dry (Fig 2). Stipe0.5-2 x 0.7$1.5 \mathrm{~cm}$ long, eccentric, rudimentary, round, solid, white and smooth. Basidiospores5.01$9.04 \times 2.39-3.54 \mu \mathrm{m}$, cylindric to ellipsoid, smooth (Fig 3). Spore print white.

\section{Colony morphology}

The colony of the native strain, on PDA medium, was floccose, no zones, white, with abundant aerial hyphaend had irregular margin. No exudates were observed (Fig 4). Reverse of the colony was off white (Fig 5). The isolate grew at a steady rate of 8.75 $\mathrm{mm} /$ day up to the $5^{\text {th }}$ day and at $16 \mathrm{~mm} /$ day from $5^{\text {th }}$ to $8^{\text {th }}$ day. The overall growth rate was $13.8 \mathrm{~mm} /$ day (Fig 6).

\section{Proximate and Mineral analysis}

The result of the Proximate analysis of domesticated and wild mushroom species are presented in the table 1. Domesticated mushroom showed appreciable amount of total carbohydrate $(77.06 \mathrm{~g})$, fiber $(34.30 \mathrm{~g})$, protein $(9.48 \mathrm{~g})$, ash $(1.28 \mathrm{~g})$ and very low fat $(0.80 \mathrm{~g})$ contents $(\mathrm{g} / \mathrm{kg})$ on dry weight basis. The Calorie value of this domesticated mushroom was higher than the wild mushroom at353.36 kcal/100g and 274.7 $\mathrm{kcal} / 100 \mathrm{~g}$ respectively. The wild specimen had higher protein (12.9g) and fat $(1.5 \mathrm{~g})$ contents $(\mathrm{g} / 100 \mathrm{~g})$, the carbohydrate content $(52.4 \mathrm{~g})$ was lower than the cultivated strain. In the native strain significant amount of fiber has been observed which indicated that the strain could be a good source of dietary fiber supplement. Mineral analysis revealed a high level of $K(2474.76 \mathrm{mg} / 100 \mathrm{~g})$ followed by $\mathrm{Mg}, \mathrm{Na}$ and $\mathrm{Ca}$. The lowest concentration among the major elements $(\mathrm{K}, \mathrm{Mg}, \mathrm{Na} \& \mathrm{Ca})$ was $\mathrm{Ca}$ at $6.77 \%$.Trace elements iron $(\mathrm{Fe})$, manganese $(\mathrm{Mn})$ and copper $(\mathrm{Cu})$ were also detected at the concentration levels 3.89, 3.28 and $2.05 \mathrm{mg} / 100 \mathrm{~g}$, respectively (Table 1 ).

\section{Cultivation}

Oyster mushrooms can grow in a wide range of agricultural wastes and this strain is no exception. From an economic view point rice straw, being the most abundant agri-waste of this region, was chosen as substrate for cultivation. As the wild mushroom was found growing on wood shavings in their natural habitat, saw dust was incorporated at $25 \%$ along with paddy straw. Polypropylene substrate bags $(30 \times 25 \mathrm{~cm})$ were prepared in three replications during the $1^{\text {st }}$ week of every month. The experiment was done in three replications.

\section{Spawn run and appearance of fruiting body}

The data of different attributing parameters during the period of cultivation were recorded and analysed (Table 2). The ambient temperature and relative humidity of the incubation room ranged from $19.7^{\circ}-36.8^{\circ} \mathrm{C}$ and 33\%-88\% respectively. The cropping room ambient temperature and relative humidity during the period of experiment ranged from $14.6^{\circ}-37.4^{\circ} \mathrm{C}$ and $33-88 \%$, respectively.

Completion of spawn run or colonization of substrate bags, which ranged from 13-15 days, were not affected by temperature and humidity variations. Days taken for pin head or primordia formation differed with variations of temperature. During the summer 
months (June-September) when the temperatures ranged between 34.1 to $37.4^{\circ} \mathrm{C}$ pinheads appeared in 7-9 days. During the winter months (November-January) when minimum temperatures ranged between 14.6 to $16.8^{\circ} \mathrm{C}$ pinheads took $23-34$ days to appear. Pinheads were white and appeared in bunches (Fig. 7). The period of maturation i.e. from pinhead formation to harvesting depended on the relative humidity conditions. During the monsoon season when the humidity was high, the maturation period varied from 5-8 days (Fig. 8). However during the winter months when low humidity conditions prevailed, the harvesting time was 3-4 days. The cropping cycle or the duration from inoculation to harvest of $3^{\text {rd }}$ flush ranged from 57-102 days. It varied inversely with temperature, requiring less than 60 days from May to August and taking as long as 102 days in December, when the temperature decreased. From May to September when temperatures ranged from $31.5^{\circ}-37.4^{\circ} \mathrm{C}$ the biological efficiency (BE) ranged between $54.3 \pm 0$ to69.2 \pm 0 . With the decrease of temperature during the winter months, October to January, the BE reduced to $32.8 \pm 1.39$ to $34.6 \pm 1.44$ (Table 2).

Table.1 Proximate and mineral composition of P. pulmonarious (dry wt basis)

\begin{tabular}{|l|c|c|c|c|}
\hline \multicolumn{3}{|c|}{ Proximate analysis } & \multicolumn{2}{c|}{$\begin{array}{c}\text { Mineral content of domesticated } \\
\text { sample }\end{array}$} \\
\hline Parameters & $\begin{array}{c}\text { Domesticated } \\
(\mathrm{g} / 100 \mathrm{~g})\end{array}$ & $\begin{array}{c}\text { Wild } \\
(\mathrm{g} / 100 \mathrm{~g})\end{array}$ & Elements & $\begin{array}{c}\text { Quantity } \\
(\mathrm{mg} / 100 \mathrm{~g})\end{array}$ \\
\hline Moisture & 11.37 & 15.2 & Potassium & 2474.76 \\
\hline Crude protein & 9.48 & 12.9 & Magnesium & 193.25 \\
\hline Crude fat & 0.80 & 1.5 & Sodium & 118.65 \\
\hline Ash & 1.28 & 0.9 & Calcium & 6.77 \\
\hline Crude fiber & 34.30 & 30.8 & Iron & 3.89 \\
\hline Total Carbohydrate & 77.06 & 52.4 & Manganese & 3.28 \\
\hline Calorie value (kcal) & 353.36 & 274.7 & Copper & 2.05 \\
\hline
\end{tabular}

Table.2 Parameters of cultivation trial

\begin{tabular}{|c|c|c|c|c|c|c|c|c|}
\hline \multirow[t]{2}{*}{ Month } & \multirow{2}{*}{$\begin{array}{c}\text { SR } \\
\text { (days) }\end{array}$} & \multirow{2}{*}{$\begin{array}{c}\mathbf{P H} \\
\text { (days) }\end{array}$} & \multirow{2}{*}{$\begin{array}{c}\mathbf{C C} \\
\text { (days) }\end{array}$} & \multirow{2}{*}{$\begin{array}{l}\text { BE } \\
(\%)\end{array}$} & \multicolumn{2}{|c|}{ Temperature $\left({ }^{\circ} \mathbf{C}\right)$} & \multicolumn{2}{|c|}{ Humidity (\%) } \\
\hline & & & & & Min & $\operatorname{Max}$ & Min & $\operatorname{Max}$ \\
\hline June & $15 \pm 0.0000$ & $7.3 \pm 0.5774$ & $59.3 \pm 2.3094$ & $69.2 \pm 0.7217$ & 26.1 & 34.1 & 57 & 88 \\
\hline July & $15 \pm 0.0000$ & $8.0 \pm 0.0000$ & $58.7 \pm 1.1547$ & $66.5 \pm 0.9014$ & 27.3 & 35.8 & 51 & 85 \\
\hline August & $14 \pm 0.5774$ & $8.3 \pm 0.5774$ & $57.7 \pm 1.1547$ & $62.2 \pm 0.8780$ & 26.9 & 37.4 & 52 & 85 \\
\hline September & $15 \pm 0.0000$ & $8.7 \pm 1.1547$ & $62.7 \pm 2.8868$ & $54.3 \pm 0.6292$ & 26.1 & 35.2 & 52 & 85 \\
\hline October & $14 \pm 0.0000$ & $19.3 \pm 1.1547$ & $87.0 \pm 2.6458$ & $36.2 \pm 1.1273$ & 19.7 & 33.7 & 45 & 80 \\
\hline November & $14 \pm 0.0000$ & $25.3 \pm 1.1547$ & $95.0 \pm 3.0000$ & $32.8 \pm 1.3919$ & 15.3 & 27.4 & 45 & 80 \\
\hline December & $14 \pm 0.0000$ & $34.0 \pm 0.0000$ & $102.7 \pm 1.5275$ & $34.2 \pm 1.4434$ & 14.6 & 26.1 & 44 & 78 \\
\hline January & $15 \pm 0.0000$ & $23.0 \pm 0.0000$ & $82.3 \pm 0.5774$ & $34.6 \pm 1.4434$ & 16.8 & 22.5 & 33 & 77 \\
\hline February & $14 \pm 0.0000$ & $19.3 \pm 0.5774$ & $69.7 \pm 2.0817$ & $41.8 \pm 1.3769$ & 17.8 & 25.7 & 36 & 73 \\
\hline March & $14 \pm 0.0000$ & $17.3 \pm 0.5774$ & $65.7 \pm 1.1547$ & $46.7 \pm 1.9094$ & 20.1 & 29.1 & 39 & 76 \\
\hline April & $14 \pm 0.0000$ & $16.0 \pm 1.7321$ & $62.0 \pm 3.0000$ & $49.7 \pm 1.3769$ & 23.4 & 30.7 & 41 & 79 \\
\hline May & $14 \pm 0.0000$ & $11.7 \pm 1.1547$ & $57.7 \pm 1.5275$ & $57.1 \pm 1.9094$ & 26.3 & 31.5 & 71 & 88 \\
\hline
\end{tabular}


Fig.1 Mature sporocarp

Fig.2. Reverse side

Fig.3 Basidiospores
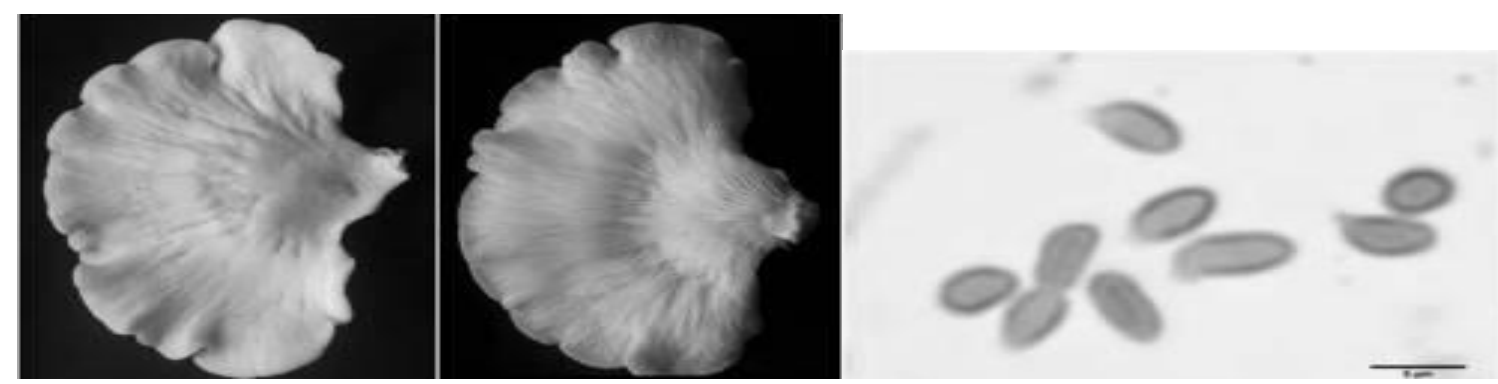

Fig.4 Fully colonized plate Fig.5 Reverse side of colony

Fig.6 Growth kinetics
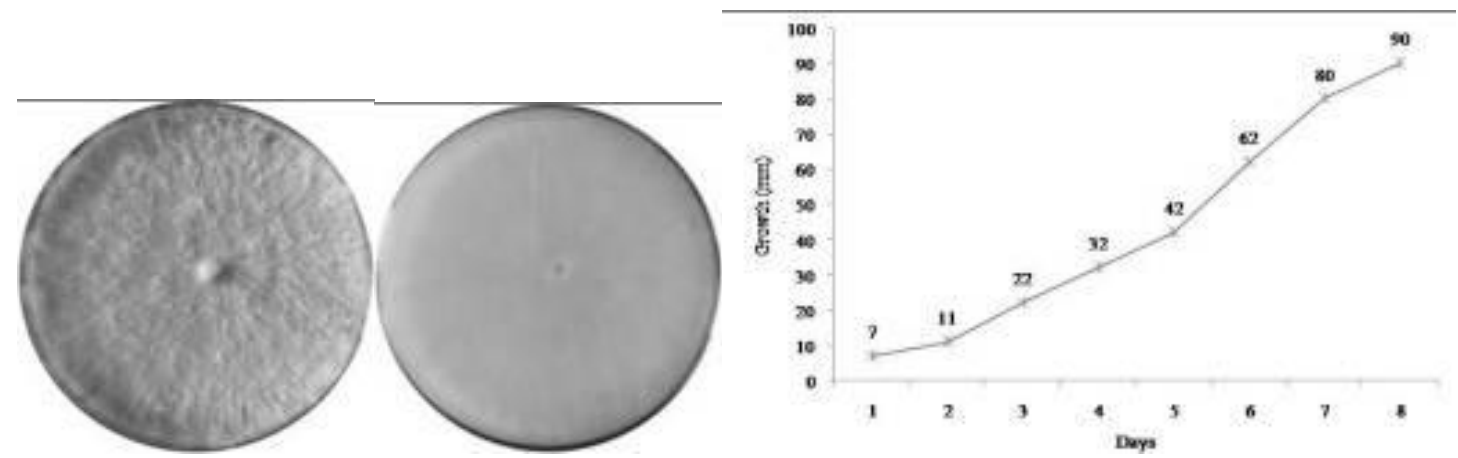

Fig.7 Appearance of pinheads

Fig.8 Mature fruiting bodies
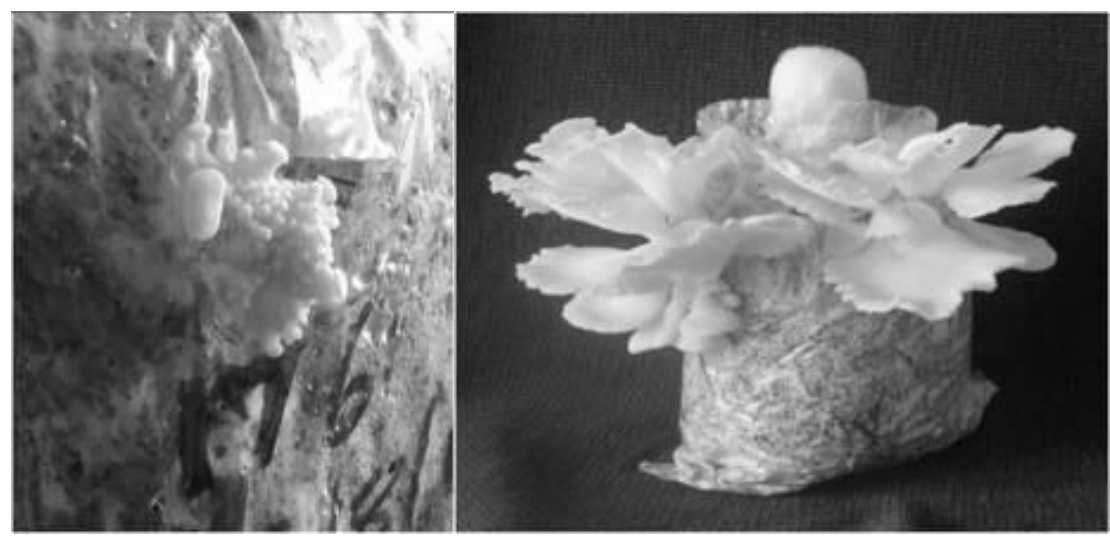

Fig.9 Monthly yield data

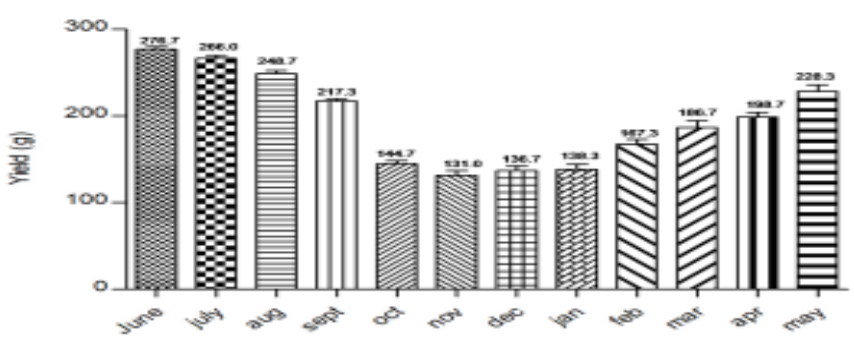




\section{Yield}

The yield increased with the raised in temperature. The average yield per bag varied from $131.0-276.7 \mathrm{~g}$ for the period of the trial with ambient temperature ranging from $14.6^{\circ} \mathrm{C}-37.4^{\circ} \mathrm{C}$. The yield from May to September when the minimum temperature ranged from $26.1^{\circ} \mathrm{C}-27.3^{\circ} \mathrm{C}$ was between 217.3-276.7g. However during the months from October to January when minimum temperatures decreased ranging between $19.7^{\circ} \mathrm{C}-14.6^{\circ} \mathrm{C}$ reduction of yield $(131.0$ $144.7 \mathrm{~g}$ ) was observed. The optimum condition for maximum yield of this strain was the months of June and July at $276.7 \mathrm{~g}$ and $266.0 \mathrm{~g}$ respectively. The temperature during this period ranged from $26.1^{\circ} \mathrm{C}-35.8^{\circ} \mathrm{C}$ (Fig 9). This strain showed a preference for warmer climate as reflected by the yield per $\mathrm{kg}$ of fresh substrate.

The pileus size $4-15 \mathrm{~cm}$ of this native strain is similar to the characteristics reported by Hemalatha et al., (2018) where pileus size ranged from $5.2-16 \mathrm{~cm}$, the stipe size however showed variations. The colony characteristics observed in the native strain was similar to the two reference strains investigated by Sobal et al., (2017) with the exception that the native strain had a higher growth rate.

Results of the proximate composition are not consistent with the earlier work (Abulude et al., 2018). Mushrooms are highly priced due to the presence of considerable amount of carbohydrate. The native strain seems to be richer in carbohydrate content than protein. Oloruntola and Omotosho (2019) observed $21.17 \%$ protein content on dry weight basis. Moreover this mushroom species is very rich in fiber. Which is important for diseases prevention and good bowel health. The high levels of major elements $\mathrm{K}, \mathrm{Mg}, \mathrm{Na}$ and minor elements $\mathrm{Mn}$ and $\mathrm{Cu}$ are in agreement with Abulude et al., (2018) with the exception of levels of $\mathrm{Ca}$ and protein content. The findings of biochemical analysis of this native strain would act as significant basis to determine its nutritional benefit. Considering the above results this mushroom is ideal as a functional food to promote human health. Although mushrooms are not fair substitute of animal protein, the native $P$. pulmonarius strain with $9.87 \%$ protein content could be suitable culinary to minimize the protein deficiency.

This native strain showed better tolerance to temperature and humidity variations at 14$37^{\circ} \mathrm{C}$ and $33-88 \%$ respectively as compared to the strain reported by Stamets (2000) at 18$29^{\circ} \mathrm{C}$ and $85-100 \%$ respectively. Bioefficiency of mushroom species is also dependent on strains. Myronycheva et al., (2017) conducted experiments with six $P$. pulmonarius strains, one from IBK, Ukraine and 5 from Penn State University (USA). The findings of our study are consistent with the previous study with bioefficiency range $32.8 \pm 1.4 \%$ to $69.2 \pm 0.7 \%$ and vegetative growth range of $14-15$ days (Myronycheva et al., 2017). Cultivation of this strain is worthwhile due to its better price than other mushrooms as reported by Wu et al., (2019). In the present investigation it has been observed that the native strain has excellent self-life, more than a week in the refrigerator without spoilage and can be dried easily. Moreover the native strain can be grown year round in wide ranging variations of temperature and humidity. The Same Chemical composition in cultivated and wild $P$. pulmonarius indicates that the cultivated $P$. pulmonarius is not less nutritious than the wild ones. This is similar to the earlier observation who reported presence of important nutrient in both wild and cultivated mushroom (Adedokun and Okomadu, 2016).

Fresh oyster mushrooms are sold @ Rs120Rs150/kg in local markets during the months 
of April-August. Dried oyster mushrooms are available throughout the year @ Rs 300/kg (Roy et al., 2017). Many educated unemployed youth of remote villages in Assam were earning a decent living by mushroom cultivation. The produce could not be sold as markets were closed due to Covid19 induced lockdown. The prevailing weather conditions hampered the drying of mushrooms, so the mushrooms rotted and caused considerable financial losses (Correspondent, 2020).Cultivation of this native strain could be an alternative option to mitigate such problems faced by the mushroom growers. Moreover mushrooms can also be preserved by making value added products i.e. mushroom chutney, candy etc and sold later.

In conclusion the present investigation reveals the new perspective of year round cultivation of the native wild edible strain. Since it is one of the expensive mushroom species, commercial production of this mushroom will help in upliftment of socio-economic status and sustenance of the rural populace. These important forest resources need to be explore extensively else it will remain hidden in the forest and become extinct.

\section{References}

Abulude, F.O., M.M. Ndamitso, A. Akinnusotu, J.J. Elisha and Makinde, O.E. 2018. Proximate Composition, Mineral Contents and the effects of Sodium Sulphate Salts on Emulsion Capacity and Stability of Mushroom Species obtained from Nigeria. Iraqi Journal of Science. 59 (2C): 986-997.

Adedokun, O.M., and Okomadu, C.A. 2016. Wild and domesticated mushroom comsumption in Nigeria. African Crop Science Journal.25 (1): 123-131. DOI: http://dx.doi.org/10.4314/acsj.v25i1.9

Adewoyin, A.G., and Ayandele, A.A. 2018.
Comparative study of yield performance and nutrient composition of the edible mushroom. Pleurotus pulmonarius, cultivated on different substrates. African Journal of Plant Science.12(8): $\quad$ 148-154. DOI: 10.5897/AJPS2018.1678

AOAC1990. Official methods of analysis of the association of official analytical chemists, $15^{\text {th }}$ ed, Arlington Virginia, USA: AOAC, 1-50.

Badole, S.L., N.M. Patel, P.A. Thakurdesai and Bodhankar, S.I. 2008. Interaction of aqueous extract of Pleurotus pulmonarius (Fr.) Quel-Champ. With glyburide in alloxan induced diabetic mice. Avidence-Based Complementary and Alternative medicine 5 (2): 159164. doi:10.1093/ecam/nem010

Chang, S.T., and Miles, P.G. 2004. Mushroom cultivation, nutritional value, medicinal effect and environmental impact. pp: 451.

Correspondent. 2020. Kalaigaon mushroom farmers suffer massive losses. The Assam Tribune, RN-1127/57 TECH/GH-103/2018-2020 82 (111).

Courtenay, B., and Burdsall, H.H. 1982. A field guide to mushrooms and their relatives, Van Nostrand Reinhold Company, New York, pp 125.

Guadarrama-Mendoza, P.C., G. Valencia del Toro, R. Ramirez-Carrillo, F. RoblesMartinez, J. Yanez-Fernandez, M.E. Garin-Aguilar, C.G. Hernandez and Bravo-Villa, G. 2014. Morphology and mycelia growth rate of Pleurotus spp. Strains from the Mexican mixtec region. Brazilian Journal of Microbiology.45(3): 861872.doi: 10.1590/s151783822014000300016

Healing-mushrooms.net Pleurotus pulmonarius: Phoenix oyster mushroom identification \& benefits.

Hemalatha, P., K.B. Mohapatra, N. Nayak 
and Chinara, N. 2018. Growth pattern, fruit body characteristics and period of spawning on yield and yield attributing parameters of Indian oyster mushroom, Pleurotus pulmonarius. International Journal of Current Microbiology and Applied Sciences. 7 (10): 3632-3637

Hussein,. J.M, D. D. Tibuhwa, A.M. Mshandete and Kivaisi, A.K. 2015. Antioxidant properties of seven wild edible mushrooms from Tanzania. African Journal of Food Science. 9(9): 471-479. DOI: $10.5897 /$ AJFS2015.1328

Ibadallah, B.X., N. Abdullah and Shuib, A.S. 2015. Identification of angiotensinconverting enzyme inhibitory proteins from mycelium of Pleurotus pulmonarius (Oyster mushroom). Planta Med. 81 (02): 123129.DOI: $10.1055 / \mathrm{s}-0034-1383409$

Jose, N., T.A. Ajith and Janardhana, K.K. 2002. Antioxidant, anti-inflammatory and antitumor activities of CulinaryMedicinal mushroom Pleurotus pulmonarius (Fr.) Quel. (Agaricomycetideae). International Journal of Medicinal Mushrooms.4:329-335. DOI:10.1615/INTJMEDMUSHR

Junior, N.M., T. Asai, M. Capelari and Meirelles, L.D.P. 2010. Morphological and molecular identification of four Brazilian commercial isolates of Pleurotus spp. and cultivation on corncob. Brazilian Archives of Biology and Technology.53 (2): 397 408.http://dx.doi.org/10.1590/S151689132010000200019.

Kumar, K. 2015. Role of edible mushroom as functional foods - A review. South Asian Journal of Food Technology and Environment.1 (3\&4): 211-218.

Kuo, M. 2017. Pleurotus pulmonarius, Retrieved from the Mushroom Expert. com Web site: http://www.mushroomexpert.com/pleur otus_pulmonarius.html.

Myronycheva, O., I. Bandura, N. Bisko, A.P. Gryganskyi and Karlsson, O. 2017. Assessment of the growth and fruiting of 19 oyster mushroom strains for indoor cultivation on lignocellulosic wastes. Bio Resources.12 (3): 46064626.

Oloruntola, A., and Omotosho, O. 2019. Proximate analysis, Phytochemical screening and mineral content of Pleurotus pulmonarius (Oyster mushroom). Current Developments in Nutrition. 3(1). DOI:10.1093/cdn/nzz040.P20-019-19)

Rai, M., G. Tidke and Wasser, S.P. 2005. Therapeutic potential of mushrooms. Natural Product Radiation. 4(4): 246257.

Roy, D.A., A.K. Saha, S.R. Joshi and Das, P. 2017. Wild edible macrofungi consumed by ethnic tribes of Tripura in Northeast India with special reference to antibacterial activity of Pleurotus djamor (Rumph. ex Fr.) Boedijn. International Food Research Journal.24(2): 834-838.

Smiderle, F.R., L.M. Olsen, E.R. Carbonero, C.H. Baggio, C.S. Freitas, R. Marcon, A.R.S. Santos, P.A.J. Gorin and Lacomini, M. 2008. Anti-inflammatory and analgesic properties in a rodent model of a (1-3), (1-6) linked $\beta$-Glucan isolated from Pleurotus pulmonarius. European Journal of Pharmacology. 597 (1-3): 86-91.

Sobal, M., D. Martinez-Carrera, P. Morales and Roussos, S. 2007. Classical characterization of mushroom genetic resources from temperate and tropical regions of Mexico. Micologia Aplicada International. 19 (1): 15-23.

Stamets, P., 2000. Growing gourmet and medicinal mushrooms, Ten speed press, Berkeley and Toronto. Pp. 3339.

Wu, N., F. Tian, O. Moodley, B. Song, C. Jia, 
J. Ye, R. Lv, Z.Qin and Li, C. 2019. Optimization of agro-residues as substrates for Pleurotus pulmonarius production. AMB Express. 9:184.
F. 2016. Effects of processing on carbendazim residue in Pleurotus ostreatus. Food Science \& Nutrition. 4(4): 645-650. DOI: $10.1002 / \mathrm{fsn} 3.328$

Xia, E., W. Tao, X. Yao, J. Wang and Tang,

\section{How to cite this article:}

Sewali Goswami, Imtiaz Rahman and Sanjai Kumar Dwivedi. 2020. Characterization and Domestication of Wild Culinary Medicinal Mushroom Pleurotus pulmonarius from Assam, India. Int.J.Curr.Microbiol.App.Sci. 9(10): 3162-3171.

doi: https://doi.org/10.20546/ijcmas.2020.910.379 